\title{
Coronary artery disease in women
}

\author{
Dominika Duda-Pyszny, Przemysław Trzeciak, Mariusz Gąsior \\ $3^{\text {rd }}$ Department of Cardiology, SMDZ in Zabrze, Medical University in Katowice, Silesian Center for Heart \\ Diseases, Zabrze, Poland
}

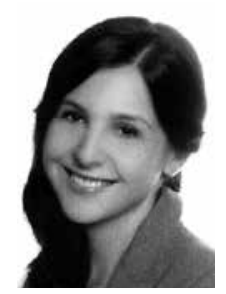

Kardiochirurgia i Torakochirurgia Polska 2018; 15 (1): 44-48

\begin{abstract}
Cardiovascular diseases, including coronary artery disease (CAD), are the leading cause of death among women and men. Mortality among women is higher than in men. Women more often report atypical anginal symptoms. Non-invasive diagnostic testing of CAD is less sensitive and characteristic in women than in men. Coronary angiography and rewascularization of coronary arteries is less common in women. However, women, who undergo angiography have lower rates of obstructive CAD. The worse prognosis of CAD in women is associated with the fact that the onset of obstructive coronary artery disease in women occurs 7-10 years later than in men. Older women are also more often burdened with comorbidities. The aim of this study was to compare the clinical characteristics, diagnostics, and treatment of CAD in women and men.
\end{abstract}

Key words: coronary artery disease, women, prognosis.

\section{Introduction}

In Europe, cardiovascular diseases are responsible for approximately 4 million deaths a year among both women and men [1]. The reduction in coronary artery disease (CAD) mortality does not include women over 75 years of age; consequently, CAD mortality is higher among women than men (23\% vs. $21 \%$ ) [2]. The prognosis for patients with stable CAD is thus not homogeneously favorable. The risk of CAD development rises after the age of 40 in both men and women [3], but significant changes in coronary arteries are observed, on average, 7-10 years later in women than in men [2, 4]. In women, the issue of CAD is underestimated, which results in its underdiagnosis and undertreatment [2]. Therefore, the aim of this study was to compare the clinical characteristics, diagnostics, and treatment of stable CAD in women and men.

\section{Clinical characteristics - differences \\ Coronary artery disease symptoms}

Diagnosing angina pectoris is based on medical interviews. Unfortunately, clinical practice shows that there

\section{Streszczenie}

Choroby sercowo-naczyniowe, w tym choroba wieńcowa (CAD), są główną przyczyną zgonów u kobiet i mężczyzn. Liczba zgonów z powodu CAD jest wyższa u kobiet niż u mężczyzn. Kobiety częściej zgłaszają nietypowe dolegliwości bólowe w klatce piersiowej. Diagnostyka nieinwazyjna CAD jest mniej czuła i swoista u kobiet niż u mężczyzn. Koronarografię i rewaskularyzację tętnic wieńcowych wykonuje się rzadziej u kobiet, natomiast w trakcie koronarografii u kobiet częściej stwierdza się nieistotne zmiany w naczyniach wieńcowych bądź „czyste naczynia wieńcowe”. Wielu autorów badań klinicznych podkreśla, że gorsze rokowanie u kobiet z CAD wiąże się z faktem, iż kobiety zapadają na chorobę wieńcową 7-10 lat później niż mężczyźni. Ponadto kobiety w starszym wieku są bardziej obciążone chorobami wspótistniejącymi. Celem niniejszej pracy jest porównanie charakterystyki klinicznej, diagnostyki i leczenia CAD u kobiet i mężczyzn.

Słowa kluczowe: choroba wieńcowa, kobiety, rokowanie.

are significant differences in symptoms between men and women. This is particularly important because the data gathered during interviews and the degree of symptoms initiates the diagnostic process. The symptoms of angina pectoris as the first manifestation of coronary artery disease differ among men and women [5]. Women are more likely to report atypical or uncharacteristic chest pain accompanied by increased sweating, dyspnea, nausea, and vomiting, which, in most cases, does not lead to further non-invasive CAD diagnostics [2]. This has been confirmed by the results of the CLARIFY registry (Prospective Observational Longitudinal Registry of Patients With Stable Coronary Artery Disease), in which women reported chest pain more often than men (28\% vs. $20 \%$ ) [6]. Moreover, it has been demonstrated that women over 75 years of age predominated among asymptomatic patients, which may be associated with their low physical activity or the presence of diabetes [7]. With age chest pain becomes typical and comparable to the symptoms reported by men [7]. This may be attributed to the fact that the perceived intensity of

\footnotetext{
Address for correspondence: Dominika Duda-Pyszny MD, $3^{\text {rd }}$ Department of cardiology, SMDZ in Zabrze, Medical University in Katowice, Silesian Center for Heart Diseases, 9 Curie-Skłodowskiej St, 44-800 Zabrze, Poland, phone: +48 506744766 , fax: +48 506 744 766, e-mail: duda.dominika@wp.pl

Received: 14.05.2017, accepted: 17.06.2017.
} 
angina pectoris symptoms is not commensurate with the existing changes in coronary vessels. Table I compares the symptomatology of stable CAD in women and men.

\section{Risk factors}

The widely known risk factors for CAD are identical in both sexes and can be classified as modifiable or nonmodifiable. Notwithstanding, it should be stressed that their frequency and intensity varies. The non-modifiable risk factors include age and genetic burden. Smoking tobacco increases the risk of CAD in women as much as 5 times in comparison with non-smokers. Tobacco smoking in combination with oral contraception increases the risk of CAD 13 times [8]. Nicotinism in women may also be associated with the occurrence of premature menopause and, consequently, the loss of the vasodilatory influence of estrogens on coronary vessels. Studies show that active tobacco smoking accelerates menopause by 2 years and reduces the concentration of $\mathrm{HDL}$ cholesterol (more so in women than in men) [7]. It appears that tobacco smoking is a stronger CAD risk factor in women than in men, especially in individuals over the age of $50[2,8]$.

Arterial pressure, especially systolic blood pressure (SBP), is more likely to rise with age in women [2]. The development of isolated systolic arterial hypertension (ISAH; $>160 \mathrm{~mm} \mathrm{Hg}$ ) with normal diastolic values $(<90 \mathrm{~mm} \mathrm{Hg})$ is associated with an increased risk of stroke, left ventricular hypertrophy, diastolic heart failure, and all-cause mortality regardless of other risk factors [9]. A significant increase in ISAH incidence was observed among women $>55$ years of age in the Framingham Heart Study. ISAH incidence among women older than 65 is approximately 30\% [10]. The WISE study (Women's Ischemia Syndrome Evaluation) demonstrated that elevated SBP and accelerated resting heart rate during the premenopausal period were associated with thickening of the intima-media complex in carotid arteries and appearance of atherosclerotic plaque within 5-8 years after menopause, which constituted an additional CAD risk factor [11].

Hypercholesterolemia is also an independent risk factor for CAD both in women and in men. During menopause, the concentrations of total and LDL cholesterol rise by 10$14 \%$, the level of lipoprotein increases by $4-8 \%$, while the level of HDL cholesterol usually remains unchanged [12]. In women over the age of 50, the levels of total cholesterol are higher than in men [12]. Studies have shown that the concentration of total cholesterol, LDL, and lipoprotein was a stronger risk factor for developing CAD in men; in women, hypertriglyceridemia was a stronger factor $[2,7,11]$. It was demonstrated that an increase in the level of triglycerides by $1 \mathrm{mmol} / \mathrm{l}$ was related to an increase in cardiovascular risk by $32 \%$ in men and $76 \%$ in women [3].

Diabetes mellitus (DM) is another significant risk factor for CAD. Type 2 DM is associated with a higher CAD risk in women than in men [2]. Diabetes accompanied by diabetic nephropathy lasting more than 10 years is considered to be an equivalent of coronary artery disease [13]. It has been
Table I. Differences in CAD symptoms in women and men

\begin{tabular}{lcc} 
Symptoms of angina pectoris & Women & Men \\
Typical angina & + & ++ \\
\hline Atypical angina & ++ & + \\
\hline Dyspnea & ++ & ++ \\
\hline Fatigue & ++ & + \\
\hline Increased sweating & ++ & + \\
\hline Nausea and vomiting & ++ & + \\
\hline
\end{tabular}

demonstrated that mortality due to myocardial infarction is substantially higher in women with type 2 DM than in men with type $2 \mathrm{DM}$ and in women without this condition [7].

Another risk factor is constituted by obesity, especially abdominal obesity. According to WHO, body mass reduction should be recommended for patients with waist circumference $>88 \mathrm{~cm}$ (women) or $>102 \mathrm{~cm}$ (men) [13]. Study results have shown that waist circumference $>84 \mathrm{~cm}$ in men and $>71 \mathrm{~cm}$ in women is associated with increased risk of CAD development despite normal body mass index (BMI). Body mass index $>30 \mathrm{~kg} / \mathrm{m}^{2}$ increases the risk of CAD by $64 \%$ in women and by $46 \%$ in men [14].

Coronary artery disease risk factors also include reduced levels of thyroid hormones, which lead to the dysfunction of coronary microcirculation [15]. Autoimmune diseases such as rheumatoid arthritis or lupus, which are more frequent among women, also increase the risk of CAD through chronic inflammation, which underlies the development of atherosclerotic plaque [5]. Numerous studies have confirmed that premenopausal hormonal disturbances are associated with an increased risk of CAD. Women with polycystic ovary syndrome are more likely to develop type 2 DM and metabolic syndrome [7]. Women, who experience arterial hypertension, pre-eclampsia, or gestational diabetes are at risk of developing CAD in the future [12]. A Canadian clinical study published in 2014 demonstrated that $80 \%$ of patients with significant CAD were characterized by at least one cardiovascular risk factor [16]. The association between the number of risk factors and the presence of significant changes in the coronary vessels is stronger in women than in men [17]. In view of the most recent studies, hormone replacement therapy (HRT) increases the risk of CAD among women over the age of 60 . Hormone replacement therapy is currently not recommended for primary or secondary CAD prevention. The intensity of stress, especially among younger women, is also not without bearing on the development of CAD and the occurrence of acute coronary syndrome [8].

\section{Non-invasive coronary artery disease diagnostics}

The first stage of diagnostics for coronary artery disease consists in performing non-invasive examinations in patients with intermediate risk of CAD (PTP 15-85\%) based on age, sex, and the character of chest pain. The 
most accessible and widely used examination is an exercise stress test. Women are more likely than men to exhibit non-specific changes in resting ECG, lower voltage of QRS complexes, high resting heart rate, and longer QT intervals [11], which, combined with the smaller diameters of coronary vessels and lower fitness, reduces the specificity of stress testing (sensitivity and specificity of the test in women is $60-70 \%$ vs. $80 \%$ in men) [2]. According to recent data, women undergoing electrocardiographic stress testing do not exceed 4.7 METs (metabolic equivalent of tasks) due to submaximal heart rate; in other words they are only able to pass the first stage of the test according to the Bruce protocol [6]. Women achieving < 5 METs in stress tests should be referred for additional stress imaging [5]. Therefore, electrocardiographic stress testing is not recommended in women, especially if other diagnostic methods (e.g., stress echocardiography) are available. Stress echo is recommended by the European Society of Cardiology (ESC), and its diagnostic accuracy is higher than that of regular stress tests (sensitivity $84 \%$, specificity $70 \%$ ). However, it appears that this method may not be the optimal diagnostic option in obese and large-breasted women due to numerous artifacts [5]. Therefore, perfusion scintigraphy (single-photon emission computed tomography - SPECT), especially using the technetium isotope Tc-99m is recommended for women as it reduces artifacts associated with excessive adipose tissue [5]. The method's sensitivity and specificity amount to $85 \%$ and $70 \%$, respectively, both in women and in men [5]. According to the ESC guidelines on the diagnosis and treatment of stable CAD, CT angiography is recommended in younger patients with PTP $<15 \%$ in whom the priority is to exclude CAD [18].

\section{Management according to cardiovascular risk}

Coronary artery disease diagnostics are based on identifying individuals with angina pectoris in whom coronary angiography and revascularization can improve prognosis by reducing cardiovascular risk, including the risk of death. Risk stratification is based primarily on clinical assessment, evaluation of the left ventricular systolic function, and results of non-invasive examinations. The stratification of cardiovascular risk is identical for both sexes. High cardiovascular risk is defined as exceeding $3 \%$ per year. In view of the ESC guidelines, CAD patients are considered to be at high cardiovascular risk when they present with anginal pain with concomitant impairment of the global/regional left ventricular systolic function (LVEF $<50 \%$ ). In such patients, coronary angiography is recommended without the need to perform non-invasive examinations [18]. The evaluation of cardiovascular risk using exercise tests is based on the Duke Treadmill Score, which depends on: the length of the exercise, changes in the ST-T segment during and after the test, and clinical symptoms. Cardiovascular death risk exceeding $3 \%$ according to the test is an indication for coronary angiography. In the case of dobutamine stress echocardiography, patients are considered at high cardio- vascular risk when disorders of left ventricular systolic function involve 3 or more segments. In the case of SPECT examinations, the presence of an ischemic area exceeding $10 \%$ of the myocardium is an indication for coronary angiography. In turn, if computed tomography (CT) angiography reveals significant stenosis in the proximal segment of the anterior descending artery, 3-vessel disease with proximal stenoses, or stenosis of the left coronary artery trunk, the patient must be referred for coronary angiography. Low or intermediate risk is an indication for optimal conservative treatment; if no improvement is achieved, coronary angiography should be considered. Summing up, high PTP ( $>85 \%$ based on clinical assessment), LVEF $<50 \%$ with anginal pain, contractility disturbances in 3 or more segments according to dobutamine stress echocardiography, perfusion decreasing by $>10 \%$ according to SPECT, and high-risk changes in CT angiography indicate high cardiovascular risk, which means that the patient should be referred for coronary angiography.

\section{Comprehensive interpretation of angiographic images in women}

Coronary angiography remains the gold standard for diagnosing significant coronary artery stenosis in both men and women. Results of large multicenter registries of stable CAD confirm that women are more likely than men to receive the diagnosis of insignificant atherosclerotic changes or "clear coronary vessels". Apart from coronary atherosclerosis, myocardial ischemia can be caused by excessive vasospasticity of coronary arteries, microcirculatory dysfunction, or spontaneous dissection of arteries unaffected by atherosclerosis [2]. The WISE study reported that coronary angiography revealed significant changes in the coronary vessels of only $31 \%$ of the female patients. In turn, insignificant changes and "clear coronary vessels" were diagnosed, respectively, in $32 \%$ and $37 \%$ of the patients [16]. In the same study, $45 \%$ out of 160 women with angina pectoris and insignificant changes in coronary arteries exhibited an abnormal response after the administration of adenosine as well as a reduction in coronary reserve [2]. Additionally, apart from microvascular dysfunction, atherosclerosis masked by positive vascular remodeling was found in the coronary arteries using intravascular ultrasonography (IVUS). The study demonstrated that this presentation of coronary vessels was associated with a 2.5fold increase in the risk of myocardial infarction, stroke, or sudden cardiac death within 1 year [2]. The percentage of patients undergoing coronary angiography in the CLARIFY study amounted to $79 \%$ in women and $86.5 \%$ in men $(p<0.0001)$ [6]. Among patients with significant changes in coronary vessels, multivessel disease was found more often in men, while single-vessel disease was more frequent in women [6]. Notwithstanding, no significant (> 50\%) coronary changes have been visualized in most women, not even in single vessels [2]. In turn, according to a German registry of coronary angiographies and percutaneous coronary interventions, encompassing approximately 1 million 
procedures, women were more likely to report CCS class II or III angina pectoris, which resulted in coronary angiographies being performed significantly more often in women than in men (80.4\% vs. $70.7 \%, p<0.0001)$, in contrast with the frequency of $\mathrm{PCl}(19.6 \%$ vs. $29.3 \%, p<0.0001)$. In the registry, vessels without atherosclerotic changes or with changes $<50 \%$ were reported more frequently in women than in men [19].

\section{Treatment}

The aim of CAD treatment is to reduce the symptoms of angina pectoris and improve the prognosis through both pharmacotherapy and revascularization. The efficacy of the individual groups of agents used for pharmacotherapy is comparable in men and women. However, a number of clinical studies suggest that women were less likely than men to receive optimal pharmacological treatment. In the Euro Heart Survey study, women were less likely to be recommended antiplatelets and statins or undergo coronary angiography [20]. The same study confirmed significant changes in the coronary vessels of $63 \%$ of the studied women and $87 \%$ of the men, while percutaneous coronary intervention $(\mathrm{PCI})$ and coronary artery bypass grafting (CABG) was performed in a total of $13 \%$ of the women and $29 \%$ of the men [20]. Women with CAD confirmed by coronary angiography were less likely to achieve complete abatement of chest pain during follow-up (43\% vs. $54 \%, p=0.007$ ) [2]. This was a consequence of narrower coronary arteries, advanced age, and the presence of concomitant diseases. Prognosis (considering age) was similar, but multifactorial analysis of survival in women with confirmed CAD showed less favorable results in women than in men; during a 1-year follow-up, the risk of death or non-fatal myocardial infarction was twice as high $[2,20]$. The CLARIFY study also showed that PCI and CABG procedures were performed less frequently in women than in men [6]. However, during a 1-year follow-up, no significant intergroup differences were demonstrated in terms of prevalence of major adverse cardiovascular events (MACE) including: cardiovascular deaths, non-fatal myocardial infarctions, and cerebral strokes [6]. The Euro Heart Survey study found that in-hospital mortality after CABG procedures was twice as high among women than it was among men [2]. Women are also more likely to suffer from intraoperative complications such as ischemic stroke or hemorrhagic complications [18]. The BARI study (Bypass Angioplasty Revascularization Investigation) demonstrated that revascularization in men and women is associated with similar benefits; no differences were noted between the sexes in terms of early or long-term mortality after $\mathrm{PCI}$ and CABG [18].

\section{Conclusions}

Women are more likely than men to report atypical chest pain. Non-invasive CAD diagnostics in women is less sensitive and specific than in men; this pertains particularly to electrocardiographic stress testing. Therefore, women should be more often referred for echocardiographic tests using dobutamine or perfusion scintigraphy (SPECT). The risk factors for the development of CAD are the same for women and men. The benefits of pharmacotherapy are similar for women and men. Women are less often administered optimal pharmacological treatment; they are also less likely to undergo coronary angiography and coronary revascularization. More than $50 \%$ of women undergoing coronary angiography receive the diagnosis of insignificant changes in the coronary vessels or "clear coronary vessels". Women undergoing percutaneous or surgical coronary revascularization are more likely to suffer from ischemic stroke or hemorrhagic complications. The in-hospital mortality rate after CABG is higher among women. Their potentially worse prognosis, underscored by authors of many clinical studies, is associated with the fact that the onset of coronary artery disease in women occurs approximately 7-10 years later than in men. Furthermore, elderly women more often suffer from concomitant diseases such as diabetes or chronic kidney disease. The results of these studies demonstrate the challenges of diagnosing and treating coronary artery disease in women.

\section{Disclosure}

Authors declare no conflict of interest.

\section{References}

1. Mozaffarian D. Heart diseases and stroke statistics. Circulation 2015; 131 : e29-322.

2. Crea F, Battipaglia I, Andreotti F. Sex differences in mechanisms, presentation and management of ischaemic heart disease. Atherosclerosis 2015; 241: 157-168.

3. Roeters van Lennep E, Westerveld HT, Erkelens DW, van der Wall EE. Risk factors for coronary heart disease: implications for gender. Cardiovasc Res 2002; 53: 538-549.

4. Sharma K, Gulati M. Coronary artery disease in women: a 2013 update. Glob Heart 2013; 8: 105-112.

5. Shaw LJ, Bairey Merz CN, Pepine CJ, Reis SE, Bittner V, Kelsey SF, Olson M, Johnson BD, Mankad S, Sharaf BL, Rogers WJ, Wessel TR, Arant CB, Pohost GM, Lerman A, Quyyumi AA, Sopko G; WISE Investigators. Insights From the NHLBI-Sponsored Women's Ischemia Syndrome Evaluation (WISE) study: part I: gender differences in traditional and novel risk Factors, symptom Evaluation, and gender-optimized diagnostic strategies. J Am Coll Cardiol Suppl 2006; 47 (3 Suppl): S4-S20.

6. Steg G, Greenlaw N, Tendera M, Ford I, Kaab S, Abergel S, Fox KM, Ferrari R CLARIFY Investigators. Women and men with stable coronary disease have similar outcomes: insights from the international prospective CLARIFY registry. Eur Heart J 2012; 33: 2831-2840.

7. Ferrari R, Abergel H, Ford I, Fox KM, Greenlaw N, Steg G, Hu D, Tendera M, Tardif JC; CLARIFY investigators. Gender-and-age related differences in clinical presentation and management of outpatients with stable coronary artery disease. Int J Cardiol 2013; 167: 2938-2943.

8. Klein LW, Nathan S. Coronary artery disease in young adults. J Am Coll Cardiol 2003; 41: 529-531.

9. Douglas S, Hoffman U, Patel MR, Mark DB, Al-Khalidi HR, Cavanaugh B, Cole J, Dolor RJ, Fordyce CB, Huang M, Khan MA, Kosinski AS, Krucoff MW, Malhotra Vm Picard MH, Udelson JE, Yow E, Cooper LS, Lee KL; PROMISE Investigators. Outcomes of anatomical versus functional testing for coronary artery disease - PROMISE trial. N Eng J Med 2015; 372: 1291-300.

10. Franklin S, Larson G, Khan A, Wong ND, Leip EP, Kannel WB, Levy D. Does the relation of blood pressure to coronary heart disease risk change with aging? The Framingham Heart Study. Circulation 2001; 103: 1245-1249.

11. Gierach GL, Johnson BD, Bairey Merz CN, Kelsey SF, Bittner V, Olson MB, Shaw LJ, Mankad S, Pepine CJ, Reis SE, Rogers WJ, Sharaf BL, Sopko G; WISE Study Group.Women's ischemia syndrome evaluation study: hypertension, 
menopause, and coronary artery disease risk in the WISE. J Am Coll Cardiol 2006; 47 (3 Suppl): S50-8.

12. Brewer C, Svatikova A, Mulvagh L. The challenges of prevention, diagnosis and treatment of ischemic heart disease in women. Cardiovasc Drugs Ther 2015; 29: 355-368.

13. Piepoli F, Hoes AW, Agewall S, Albus C, Brotons C, Catapano AL, Cooney MT, Corrà U, Cosyns B, Deaton C, Graham I, Hall MS, Hobbs FDR, Lfchen ML, Löllgen H, Marques-Vidal P, Perk J, Prescott E, Redon J, Richter DJ, Sattar N, Smulders Y, Tiberi M, van der Worp HB, van Dis I, Verschuren WMM, Binno S. Wytyczne Europejskiego Towarzystwa Kardiologicznego dotyczące prewencji chorób sercowo-naczyniowych w praktyce klinicznej. Kardiol Pol 2016; 74: 821-936.

14. Flint J, Rexrodec M, Hua FB, Glynnc RJ, Caspard H, Manson JE, Willet WC, Rimm EB. Body mass index, waist circumference, and risk of coronary heart disease: A prospective study among men and women. Obes Res Clin Pract 2010; 4: e171-e181.

15. Sara J, Zhang M, Gharib H, Lerman LO, Lerman A. Hypothyroidism is associated with coronary endothelial dysfunction in women. J Am Heart Assoc 2015; 4: e002225.

16. Merz CN, Kelsey SF, Pepine CJ, Reichek N, Reis SE, Rogers SE, Rogers WJ, Sharaf BL, Sopko G. The Women's Ischemia Syndrome Evaluation (WISE) study: protocol design, methodology and feasibility report. J Am Coll Cardiol 1999; 33: 1453-1461.

17. Ko DT, Wijeysundera HC, Undell J, Vaccarino V, Austin PC, Guo H, Velianou JL, Lau K, Tu J. Traditional cardiovascular risk factor and the presence of obstructive coronary artery in men and women. Can J Cardiol 2014; 30: 820-826.

18. Montalescot G, Sechtem U, Achenbach S, Andreotti F, Arden C, Budaj A, Bugiardini R, Crea F, Cuisset T, Di Mario C, Ferreira JR, Gersh BJ, Gitt AK, Hulot JS, Marx N, Opie LH, Pfisterer M, Prescott E, Ruschitzka F, Sabaté M, Senior R, Taggart DP, van der Wall EE, Vrints CJM. Wytyczne Europejskiego Towarzystwa Kardiologicznego dotyczące postępowania w stabilnej chorobie wieńcowej. Kardiologia Polska 2013; 71 Supl. X: 243-318.

19. Heer T, Hochadel M, Schmidt K, Mehilli J, Zahn R, Kuck K, Hamm C, Böhm M, Ertl G, Andresen D, Massberg S, Senges J, Pilz G, Gitt A, Zeymer U. Gender differences in therapeutic recommendation after diagnostic coronary angiography: insights from the Coronary Angiography and PCI Registry of the German Society of Cardiology. Clin Res Cardiol 2015; 104: 507-517.

20. Daly C, Clemens F, Sendon J, Lopez Sendon JL, Tavazzi L, Boersma E, Danchin N, Delahaye F, Gitt A, Julian D, Mulcahy D, Ruzyllo W, Thygesen K, Verheugt, Fox KM; Euro Heart Investigators. Gender differences in the management and clinical outcome of stable angina - Euro Heart Survey. Circulation 2006; 113: 490-498. 